\title{
Fundamental Rights in Europe after Opinion 2/13
}

\author{
The Hidden Promise of Mutual Trust
}

\author{
TIMOTHY ROES AND BILYANA PETKOVA
}

\section{Introduction}

Like a glamorous celebrity couple whose marital happiness glossy magazines treat with fascination, the relationship between the Court of Justice of the European Union (CJEU) and the European Court of Human Rights (ECtHR) continues to intrigue legal academia. The significant overlap between the jurisdiction of both courts would ordinarily be a recipe for judicial skirmishes, ${ }^{1}$ a risk that has only increased in recent years. While the CJEU has long reviewed European Union acts in the light of the European Convention on Human Rights (ECHR), the adoption of the Charter of Fundamental Rights as a binding instrument ${ }^{2}$ in 2009 has complicated things further. Human rights adjudication now is no longer a sideshow but the CJEU's core business, ${ }^{3}$ exacerbating the risk

The authors are indebted to Christine Landfried and Bruno de Witte for their incisive comments on an earlier draft of this chapter.

1 See, generally, Y. Shany, The Competing Jurisdictions of International Courts and Tribunals (Oxford and New York: Oxford University Press, 2004).

2 According to Article 6(1) TEU, the European Union "recognizes the rights, freedoms and principles set out in the Charter of Fundamental Rights of the European Union of 7 December 2000, as adopted at Strasbourg, on 12 December 2007, which shall have the same legal value as the Treaties."

${ }^{3}$ G. De Búrca, "After the EU Charter of Fundamental Rights: The Court of Justice as a Human Rights Adjudicator?," Maastricht Journal of European and Comparative Law 20 (2013), 168-184; T. Tridimas, "Fundamental Rights, General Principles of EU Law, and the Charter," Cambridge Yearbook of European Legal Studies 16 (2014), 361-392 [362-364]; S. Douglas-Scott, "The Court of Justice of the European Union and the European Court of Human Rights after Lisbon," in S. de Vries, U. Bernitz, and S. Weatherill (eds.), The Protection of Fundamental Rights in the EU after Lisbon (Oxford: Hart Publishing, 2013), pp. 153-180 [158]. 
of conflicts with the ECtHR. ${ }^{4}$ Yet, in contrast to the knee-jerk reactions of certain state constitutional courts at the prospect of losing business to Luxembourg, ${ }^{5}$ the ECtHR has continued to put a premium on judicial dialogue. Even though the CJEU's adverse opinion ${ }^{6}$ on the European Union's accession to the Convention came as "a great disappointment" to the Strasbourg court, ${ }^{7}$ the relationship between both supranational courts continues to be characterized by mutual trust and cross-fertilization.

This contribution takes a closer look at this productive partnership and asks whether the existing legal framework guarantees the endurance of the cooperative dialogue between both courts. First, it summarizes the ground rules of their symbiosis, going over the Convention's status in European Union law and the ECtHR's recognition of the European Union's legal personality. Then, it briefly addresses the impact of Opinion $2 / 13$ on the European Union's accession to the Convention before exploring, in section 3 , the many forms that the judicial dialogue between the CJEU and the ECtHR has taken over the years and discussing the

4 C. Eckes, "EU Accession to the ECHR: Between Autonomy and Adaptation," The Modern Law Review 76 (2013) 254-285 [280]; H. Porsdam, From Civil to Human Rights: Dialogues on Law and Humanities in the United States and Europe (Cheltenham, UK, and Northampton, MA: Edward Elgar, 2009), p. 102. Describing how such conflicts might arise, see, e.g., H. J. van Roosmalen and A. Pahladsingh, "Het Handvest van de grondrechten van de Europese Unie: beweging in de rechtspraak," NtER (2013) 3, 83-92 [86]. At the same time, Article 52(3) of the Charter intends precisely "to ensure the necessary consistency between the Charter and the ECHR" (Explanations Relating to the Charter of Fundamental Rights, OJ [2007] C 303/33) by defining the scope and meaning of fundamental rights in relation to the Convention and by referring to the level of protection set by the ECHR as European Union minimum standards.

${ }^{5}$ Procedurally, there was the introduction of the question prioritaire de constitutionalite in three different European Union member states, which was ruled incompatible with Article 267 TFEU: CJEU, Order of 1 March 2011 in Chartry, C-457/09, EU:C:2011:101 (Belgium); CJEU, Judgment in Melki and Abdeli, C-188/10 and C-189/10, EU:C:2010:363 (France); Judgment in A and B, C-112/13, EU:C:2014:2195 (Austria). Substantively, tensions between the CJEU and the national constitutional courts ran high in the context of the European Arrest Warrant. See in particular the Judgment in Melloni, C-399/11, EU: C:2013:107. See A. Pliakos and G. Anagnostaras, "Fundamental Rights and the New Battle over Legal and Judicial Supremacy: Lessons from Melloni," Yearbook of European Law 64 (2015), 97-126; D. Thym, "Separation versus Fusion: How to Accommodate National Autonomy and the Charter? Diverging Visions of the German Constitutional Court and the European Court of Justice," European Constitutional Law Review 9 (2013), 391-419.

6 CJEU, Opinion 2/13 ("Accession of the European Union to the European Convention on Human Rights”), EU:C:2014:2454.

7 D. Spielmann, "Foreword of the President of the ECtHR," Annual Report of the European Court of Human Rights (Strasbourg: Registry of the European Court of Human Rights, 2014), p. 7. 
influence of the jurisprudence of one over the other. A final part relies on the notion of systemic integration to argue that the cooperation between both courts goes beyond voluntary comity and amounts to a legal duty.

\section{Jurisdictional Overlap}

While the two courts belong to discrete legal orders, they are "forced to confront each other's existence" in several ways. The European Union is not bound by the Convention as a matter of international law because it is (still) not a party to it. ${ }^{9}$ Yet, because all European Union member states are party to it, ${ }^{10}$ the CJEU has traditionally considered the rights contained in that treaty as principles common to the constitutional traditions of the member states and, for that reason, general principles of European Union law. ${ }^{11}$ By doing so, the Court sought to avoid early on that member states violate the Convention by complying with European Union law or that they jointly incur Convention responsibility for the acts or omissions of their supranational agents, the European Union institutions. The 1992 Maastricht Treaty has codified this long-standing

8 Douglas-Scott, “The Court of Justice of the European Union,” p. 157.

9 As the CJEU put it in its judgments in Åkerberg Fransson (C-617/10, EU:C:2013:105, para. 44) and Kamberaj (C-571/10, EU:C:2012:233, para. 62) the Convention "does not constitute, as long as the European Union has not acceded to it, a legal instrument which has been formally incorporated into European Union law. Consequently, European Union law does not govern the relations between the ECHR and the legal systems of the Member States, nor does it determine the conclusions to be drawn by a national court in the event of conflict between the rights guaranteed by that convention and a rule of national law." See also CJEU, Opinion 2/13, EU:C:2014:2454, para. 179.

10 It seems clear that being party to the ECHR is one of the so-called Copenhagen criteria listing the conditions for European Union membership. See in particular the Joint Declaration by the European Parliament, the Council and the Commission, OJ (1977) C 103/1, which were confirmed by the European Council at Copenhagen on June 21 and 22, 1993 (6 EC Bull. [1993], point I.13) and are now referenced in Article 49 TEU. See K. Lenaerts, P. Van Nuffel, and N. Cambien (ed.), European Union Law (Oxford and New York: Oxford University Press, 2011), pp. 92-93 and 828.

11 See CJEU, Judgment in Internationale Handelsgesellschaft, 11/70, EU:C:1970:114, para. 4 and Judgment in Nold v. Commission, 4/73, EU:C:1974:51, para. 13. In more detail, see Lenaerts et al., European Union Law, pp. 826-829 and B. de Witte, "Community Law and National Constitutional Values," LIEI (1991), 2, 1-22. While the European Union Charter is now the Court's main source of fundamental rights, general principles of European Union law have not lost all relevance, see Tridimas, "Fundamental Rights," pp. 378-379 and H. Hofmann and C. Mihaescu, "The Relation between the Charter's Fundamental Rights and the Unwritten General Principles of EU Law: Good Administration as a Test Case," European Constitutional Law Review 9 (2013), 73-101. 
jurisprudence in the Treaty on European Union, introducing a formal reference to the Convention in the treaties. ${ }^{12}$ According to said jurisprudence, the ECHR is binding on the European Union institutions and on member states when they are acting within the scope of Union law. ${ }^{13}$ The upshot of this is that even though the European Union is not a party to the Convention, the CJEU applies (and interprets) the rights contained in the Convention, using them as a yardstick for legality review. In sum, the Convention has been fully integrated not just into the laws of the member states but also into European Union constitutional law. ${ }^{14}$

The effect of the Convention and ECtHR case law in the European Union legal order therefore remains a matter not of international but of domestic law - European Union law. ${ }^{15}$ This is particularly clear now that the Union has a binding fundamental rights catalogue of its own that explicitly addresses its relationship to the Convention. In Article 52(3), the Charter creates an "interpretive bridge" 16 between the European Union fundamental rights regime and the Convention, stipulating that

12 See Article F of the Maastricht Treaty, which became Article 6(2) TEU post-Amsterdam (1997) ("The Union shall respect fundamental rights, as guaranteed by the European Convention for the Protection of Human Rights and Fundamental Freedoms signed in Rome on 4 November 1950 and as they result from the constitutional traditions common to the Member States, as general principles of Community law"). The Lisbon Treaty, which entered into force on December 1, 2009 moved the provision to Article 6(3) TEU and slightly amended its formulation.

13 As Advocate General Sharpston observed in her opinion in Bartsch (C-427/06, EU: C:2008:297, point 69), this means that the national measure at issue must (1) implement EU law - irrespective of the degree of discretion the member state enjoys and whether the national measure goes beyond what is strictly necessary for implementation; (2) invoke some permitted derogation under European Union law, as in the Judgment in ERT, 260/ 89, EU:C:1991:254, paras. 41-45; or (3) must otherwise fall within the scope of EU law because some specific substantive rule of EU law is applicable to the situation, for instance because the national measure potentially hinders free movement, as in the Judgment in Karner, C-71/02, EU:C:2004:181, paras. 48-53.

14 See further P. Eeckhout, "Human Rights and the Autonomy of EU Law: Pluralism or Integration?," Current Legal Problems 66 (2013), 169-202 [175-180].

15 Eckes, "EU Accession," p. 280. Advocate General Jacobs put it as follows in his opinion in Bosphorus (C-84/95, EU:C:1996:179, point 53): "Although the [Union] itself is not a party to the Convention ... and although the Convention may not be formally binding upon the [Union], nevertheless for practical purposes the Convention can be regarded as part of [Union] law and can be invoked as such both in this Court and in national courts where [Union] law is in issue."

16 D. Spielmann, "The Judicial Dialogue between the European Court of Justice and the European Court of Human Rights or How to Remain Good Neighbours after the Opinion 2/13," Speech delivered at FRAME on March 27, 2017 in Brussels, www.fp7-frame.eu/wpcontent/uploads/2017/03/ECHRCJUEdialog.BRUSSELS. final.pdf. 
in so far as the Charter contains rights that "correspond" to rights guaranteed by the Convention, "the meaning and scope" of the former shall be the same as those of the latter. ${ }^{17}$ More importantly, the provision adds that this "shall not prevent Union law providing more extensive protection," thus making use of the leeway that Article 53 of the Convention leaves to contracting parties to lay down higher standards of protection of fundamental rights. In this way, the Charter treats the Convention as laying down the minimum standard below which the protection offered by the Charter may not fall. ${ }^{18}$ As a baseline, Article 53 of the Charter adds a sort of standstill clause according to which the Charter must never be interpreted as setting a lower level of protection than what European Union law, international law, the Convention, and member states' constitutions required on December 1, 2009. ${ }^{19}$ This means that it falls to the CJEU to determine in a concrete case whether European Union legislation or a national measure implementing European Union law violates the Convention or simply goes above and beyond. That determination is particularly difficult to make when two or more rights must be balanced against each other, presenting a risk of conflict between the CJEU and the ECtHR. Taken together, these provisions give the CJEU some margin of maneuver to shield European Union law from the Convention.

In this connection, it is worth remembering that Luxembourg's mission differs from Strasbourg's: where the latter strives to lay down minimum standards for the 47 parties to the Convention, the former seeks to ensure the primacy, effectiveness, and uniformity of European Union law. Hence, the ECtHR may, on the basis of Article 53 ECHR, leave a European Union member state free to provide more extensive protection - by setting a more demanding standard for what constitutes a fair trial, for instance - whereas the CJEU will deny that member state the freedom to deviate from the balance that a particular instrument of European Union law has struck between competing fundamental rights,

17 The Explanations to the Charter set out which rights "correspond" to each other.

18 On the relationship between the Charter and the Convention as prescribed by Articles 52 and 53 of the Charter, see K. Lenaerts, "The Court of Justice of the European Union and the Protection of Fundamental Rights," Polish Yearbook of International Law 31 (2011), 79-106 [98-104].

19 See the explanations to Article 53 of the Charter, C303/05 ("This provision is intended to maintain the level of protection currently afforded") and K. Lenaerts, "Die EU-Grundrechtencharta: Anwendbarkeit und Auslegung," Europarecht 47 (2012), 3-16 [13 and note 49]. 
even by setting a standard of protection that is just barely higher than the ECHR minimum standard. As Melloni demonstrates, where a situation falls within the scope of European Union law, national courts may be required to deny individuals the benefit of more demanding constitutional guarantees in the interest of the primacy, effectiveness, and uniformity of the lower common denominator set by European Union secondary law. The CJEU's role is that of a federal constitutional and supreme court, not that of a second supranational human rights court.

Conversely, while European Union acts as such cannot be challenged before the ECtHR, ${ }^{20}$ this does not prevent the Strasbourg court from adjudicating cases involving the European Union. Because the European Union is not a party to the Convention, that court lacks personal jurisdiction to consider applications against the supranational organization. ${ }^{21}$ It also rejects applications that aim to establish the individual or joint responsibility of European Union member states for European Union measures unless they involve some sort of positive action by the state on their territory, thus meeting the jurisdictional requirement posed by Article 1 of the Convention. ${ }^{22}$ For this reason, the Court dismissed the application of a former European Union official against the (then) 15 European Union member states claiming that the annulment procedure in which he had challenged his dismissal before the CJEU violated Article 6 of the Convention because it did not allow him to respond to the opinion of the advocate general. ${ }^{23}$ That said, in Kokkelvisserii, $^{24}$ Strasbourg significantly relaxed this requirement by suggesting that the mere act of requesting a preliminary ruling from the CJEU, by a state court, suffices to examine that state's responsibility for defects in the preliminary ruling procedure. Moreover, in Gaspar$\mathrm{ini}^{25}$ which concerned an employment dispute between the North Atlantic Treaty Organization (NATO) and an employee, the ECtHR even seems to have completely abandoned the requirement for the state to act, holding that the fact that the applicant alleged a "structural lacuna" in NATO's internal dispute-settlement mechanism entitled it to examine the state's Convention responsibility. The upshot is that an

${ }^{20}$ Judgment in Matthews v. UK, Application No. 24833/94, para. 32.

21 European Human Rights Commission, Confédération Française Démocratique du Travail v. the European Communities, Application No. 8030/77.

22 Douglas-Scott, “The Court of Justice of the European Union," p. 154.

23 ECtHR, Judgment in Connolly v. 15 Member States of the EU, Application No. 73274/01.

${ }^{24}$ ECtHR, Judgment in Kokkelvisseri v. The Netherlands, Application No. 13645/05.

25 ECtHR, Judgment in Gasparini v. Italy, Application No. 10750/03. 
applicant must either show that a member state directly or indirectly intervened in a European Union act or assert a structural lacuna in its internal dispute-settlement mechanism. ${ }^{26}$

In any event, when a jurisdictional nexus is present, the ECtHR may consider all acts and omissions of contracting parties and their organs, regardless of whether they were a consequence of domestic law or of the necessity to comply with international legal obligations. ${ }^{27}$ In other words, a European Union member state is not absolved from its Convention responsibility in the areas in which it has transferred power to the European Union, ${ }^{28}$ as this would allow it to determine the extent of its obligations at will, undermining the Convention's effectiveness. ${ }^{29}$ The Strasbourg court thus has jurisdiction to consider the legality of an action by a European Union member state even though that action originates in European Union law, which means that it may indirectly judge on the compatibility of European Union acts with the Convention.

Thus, in Bosphorus, the ECtHR saw no jurisdictional bar to considering whether the Irish authorities had violated Article 1 of the First Additional Protocol to the Convention by impounding an aircraft on Irish territory, notwithstanding the fact that Ireland was merely implementing a European Union regulation. ${ }^{30}$ This, however, risks putting a European Union member state in a dilemma between its loyalty to European Union law and compliance with the Convention. In effect, European Union law requires it to justify the actions or omissions for which it risks incurring Convention responsibility by relying on its

26 C. Reyngaert, “The European Court of Human Rights' Approach to the Responsibility of Member States in Connection with Acts of International Organizations," International and Comparative Law Quarterly 60 (2011), 997-1016 [1005].

ECtHR, Judgment in Bosphorus v. Ireland, Application No. 45036/98, para. 153.

28 See already Matthews v. UK, para. 32, which concerned the individual liability of a European Union member state for European Union primary law in the adoption of which it was involved. The ECtHR has also considered several cases in which the collective responsibility of all European Union member states for European Union acts or omissions was asserted, although it never imposed sanctions. See, e.g., ECtHR, Judgment in Soc Guérin Automobiles v. 15 EU Member States, Application No. 51717/ 99; ECtHR, Judgment in Segi ea and Gestoras Pro Amnestia v. 15 EU Member States, Application No. 6422/02; ECtHR, Judgment in Senator Lines v. 15 EU Member States, Application No. 56672/00.

29 Ibid., para. 154. See also Matthews v. UK, para. 22.

30 Bosphorus v. Ireland, paras. 136-138. See also T. Lock, "Beyond Bosphorus: The European Court of Human Rights' Case Law on the Responsibility of Member States of International Organisations under the European Convention on Human Rights," Human Rights Law Review 10 (2010), 529-545 [532]. 
obligations under the European Union treaties. The result would be that European Union member states would be held separately or jointly liable for European Union acts, which undermines the international legal personality of the European Union.

To avoid this, the Strasbourg Court in Bosphorus installed a rebuttable presumption that is sensitive to the margin of maneuver ("discretion") that European Union rules leave for European Union member states. Echoing the Bundesverfassungsgericht's Solange jurisprudence and picking up on the European Human Rights Commission's 1987 decision in M. \& Co. v. Germany, ${ }^{31}$ the Court held that "[a]s long as the relevant organization is considered to protect fundamental rights ... in a manner which can be considered at least equivalent to that for which the Convention provides ... the presumption will be that a State has not departed from the requirements of the Convention when it does no more than implement legal obligations flowing from its membership of the organization." 32 The ECtHR assesses whether a European Union member state's acts or omissions are mandated by European Union law - in which case the presumption of equivalent protection kicks in and the state is presumed to have complied with the Convention - or whether European Union rules left them a margin of discretion, in which case the presumption does not apply and the Court examines whether the state exercised that discretion in a Convention-compliant manner. It is worth adding that, since Michaud v. France, the Court has added an additional condition: The application of the presumption of equivalent protection requires not just the absence of any margin of maneuver on the part of the domestic authorities but also "the full deployment of the supervisory mechanism provided for by European Union law."33

Thus, in M.S.S. v. Belgium and Greece - a judgment that dates from before Michaud - the Court held that the so-called sovereignty clause in Article 3(2) of European Union Regulation 343/2003 (the Dublin

31 European Commission of Human Rights, M. \& Co. v. Germany, Application No. 13258/ 87, D.R. No. 64, p. 138 ("the Convention does not prohibit a Member State from transferring powers to international organisations".) Nonetheless, the commission recalls that "if a State contracts treaty obligations and subsequently concludes another international agreement which disables it from performing its obligations under the first treaty it will be answerable for any resulting breach of its obligations under the earlier treaty."

32 Bosphorus v. Ireland, paras. 155-156.

33 ECtHR, Judgment in Michaud v. France, Application No. 12323/11, paras. 114-115. The Court repeated that condition in its Judgment in Avotinšs v. Latvia, Application No. 17502/07, paras. 105 and 109-112. 
Regulation) allowed Belgium to refrain from transferring the applicant to Greece, where he ran a real risk of being subject to treatment contrary to Article 3 of the Convention. ${ }^{34}$ Because the measure under review therefore "did not strictly fall within Belgium's international legal obligations," the presumption of equivalent protection did not apply. Conversely, in Avotiņs v. Latvia, the ECtHR found that Article 34(2) of the Brussels I Regulation, as construed by the CJEU "in a fairly extensive body of caselaw," did not confer any discretion on national courts in deciding whether to issue a declaration of enforceability. ${ }^{35}$ Moreover, that the Latvian Supreme Court had not made a reference for a preliminary ruling to the CJEU did not mean that the supervisory mechanism provided by European Union law had not been fully deployed, as Michaud prescribed. ${ }^{36}$ Thus, the Bosphorus presumption applied.

Importantly, the Court in Bosphorus held that, even when the presumption applies, it may be rebutted if "in the circumstances of a particular case, [the Court finds] that the protection of Convention rights was manifestly deficient." 37 On its face, this formulation conveys that the ECtHR checks, every time it applies the presumption, whether the substantive and procedural guarantees afforded by the European Union legal system in a concrete case meet some sort of minimum standard derived from the Convention. Later judgments, however, suggest that the standard of review is even more deferential as the ECtHR merely makes a "wholesale" 38 assessment of the judicial protection of fundamental rights in the European Union and will see no need to consider the presumption rebutted unless those guarantees deteriorate across the board.

Moreover, in Avotiňš v. Latvia, the ECtHR has again nuanced the Bosphorus presumption by holding that "if a serious and substantiated complaint is raised before [a domestic court] to the effect that the protection of a Convention right has been manifestly deficient and that this situation cannot be remedied by European Union law, [that court] cannot

34 ECtHR, Judgment in M.S.S. v. Belgium and Greece, Application No. 30696/09, para. 365.

35 Avotiňš v. Latvia, para. 106.

36 Ibid., paras. 109-111. See P. Gragl, “An Olive Branch from Strasbourg? Interpreting the European Court of Human Rights' Resurrection of Bosphorus and Reaction to Opinion 2/ 13 in the Avotinšs Case," European Constitutional Law Review 13 (2017), 551-567 [557].

37 Bosphorus v. Ireland, para. 156.

38 See D. Halberstam, "'It's the Autonomy, Stupid!' A Modest Defense of Opinion 2/13 on EU Accession to the ECHR, and the Way Forward," German Law Journal 16 (2015) 1, 105-146 [131-134], who calls the distinction one between a "wholesale" and a "retail" examination of fundamental rights violations. 
refrain from examining that complaint on the sole ground that [it is] applying EU law." 39 This case concerned a Latvian court that, under the Brussels I Regulation, had no margin to deny granting an enforcement award of a judgment delivered by a Cypriot judge, even though there were fundamental rights objections to doing so. According to Spielmann, the judgment confirms the continued validity of the Bosphorus presumption post-Opinion $2 / 13$ but also sends a clear signal that it should not be taken for granted, that is, that the ECtHR is eager to scrutinize the decisions of domestic courts implementing European Union law. ${ }^{40}$

It is worth remarking that even outside the narrow set of cases where it is asked indirectly to consider the compatibility of European Union acts with the Convention, the Strasbourg court explicitly or implicitly deals with European Union law more often than one would surmise. ${ }^{41} \mathrm{Next}$ to the aforementioned cases of M.S.S. v. Belgium and Greece and Avotiňs v. Latvia, one may think of the line of cases in which the Court was asked whether the refusal of a national court to refer a reference for preliminary ruling to the CJEU amounts to a violation of Article $6 \mathrm{ECHR},{ }^{42}$ or of Karoussiotis, which required it to determine whether the fact that the European Commission had already started infringement proceedings against Portugal rendered an application inadmissible under Article 35 (2)(b) of the Convention. ${ }^{43}$

39 Avotiņš v. Latvia, para. 116.

40 Spielmann, “The Judicial Dialogue,” p. 15. However, Reyngaert, in “Oscillating between Embracing and Avoiding Bosphorus: The European Court of Human Rights on Member State Responsibility for Acts of International Organisations and the Case of the EU," European Law Review 39 (2014), 176-192 [191], has observed that the ECtHR has traditionally been reluctant to second-guess the human rights adequacy of the internal procedures of other international organizations, in particular the European Union. The Court is wont to avoid being drawn into this difficult exercise by taking it as a given that the European Union offers equivalent protection or by finding that there either was no positive action by a member state or that European Union law left the member state a certain margin of discretion.

41 C. Eckes, "EU Accession to the ECHR: Between Autonomy and Adaption," Modern Law Review 76 (2013), 254-285 [260-262]; S. Douglas-Scott, "A Tale of Two Courts: Luxembourg, Strasbourg and the Growing European Human Rights Acquis," Common Market Law Review 43 (2006), 629-665 [631].

42 See, for instance, ECtHR, judgments in Dhahbi v. Italy, Application No. 17120/09; Schipani and Others v. Italy, Application No. 38369/09; Ullens de Schooten and Rezabek, Application Nos. 3989/07 and 38353/07 and Ferreira, Application No. 30123/10. See further C. Lacchi, “The ECtHR's Interference in the Dialogue between National Courts and the Court of Justice of the EU: Implications for the Preliminary Reference Procedure," Review of European Administrative Law 8 (2015), 95-125.

43 ECtHR, Judgment in Karoussiotis v. Portugal, Application No. 23205/08. 
To summarize, the ground rules of engagement between Luxembourg and Strasbourg are based on a nuanced reading of the Bosphorus formula. It becomes clear, however, that the present situation, whereby the European Union is not a contracting party to the Convention, gives rise not only to an additional layer of jurisdictional complexity but also leaves an accountability gap. While the adoption of the Charter has remedied that to some extent, the European Union remains shielded from external scrutiny, which means that there is still a gap between what the European Union requires from others - notably through the Copenhagen criteria and what it does. ${ }^{44}$ For that reason, the Lisbon Treaty made accession constitutionally required. ${ }^{45}$

\section{The Impact of Opinion 2/13}

The European Union's long-planned accession to the Convention was dealt a significant blow in December 2014, when the CJEU held in Opinion 2/13 that the Draft Agreement between the 47 member states of the Council of Europe and the European Union was fundamentally incompatible with European Union primary law. The Court saw four constitutional issues with accession as envisaged by the agreement. ${ }^{46}$ First, it would upset the autonomy and specific characteristics of European Union law because the agreement (1) did nothing to prevent member states from departing from the level of protection provided for by the Charter or from otherwise compromising the primacy, unity, and effectiveness of European Union law by relying on Article 53 ECHR, which allows them to lay down higher standards of protection of fundamental rights than those guaranteed by the Convention; ${ }^{47}$ (2) failed to safeguard the principle of mutual trust between European Union

${ }^{44}$ E. Spaventa, "A Very Fearful Court? The Protection of Fundamental Rights in the European Union after Opinion 2/13," Maastricht Journal of European and Comparative Law 22 (2015), 35-56 [43] and, discussing the reasons for accession more generally, pp. 37-44.

45 Article 6(2) TEU prescribes that "[t]he Union shall accede to the European Convention for the Protection of Human Rights and Fundamental Freedoms."

46 The Court's touchstone was twofold. On the one hand, Article 6(2), second sentence, TEU, according to which the accession was not to "affect the Union's competences as defined in the Treaties." On the other hand, Protocol No. 8 relating to Article 6(2) European Union on the accession of the Union to the ECHR, which demands inter alia that the agreement "make provision for the preserving the specific characteristics of the Union and Union law" and not affect Article 344 TFEU.

47 Opinion 2/13, para. 189. 
member states, which meant that member states could be required to check that another member state has observed fundamental rights as a matter of course; and (3) would allow circumvention of the preliminary ruling procedure through the mechanism introduced by Protocol No 16, through which the highest national courts could request advisory opinions from the ECtHR on rights corresponding to those guaranteed by the Charter.

Second, accession would affect the CJEU's exclusive jurisdiction (as per Article 344 TFEU) with respect to disputes concerning the interpretation or application of the treaties because the agreement did not exclude the ECtHR from hearing disputes between member states or between member states and the European Union that concerned the application of the Convention but also fell within the scope ratione materiae of European Union law. Third, the corespondent mechanism would involve the ECtHR applying and interpreting the rules of European Union law governing the division of powers between the member states and the Union, and the CJEU's prior involvement would not allow it to rule on the interpretation of secondary European Union law. Finally, because the CJEU does not have full jurisdiction over matters relating to the European Union's Common Foreign and Security Policy, accession would confer jurisdiction to carry out a judicial review of the European Union's acts and omissions in the light of fundamental rights exclusively on an international court outside the European Union institutional framework. As the Court had already held in Opinion 1/09, that would alter the essential character of the powers that the treaties confer on the European Union institutions and on the member states and that are essential to the preservation of the very nature of European Union law. ${ }^{48}$

Many scholars have lambasted Opinion 2/13 for being focused more "on protecting [the Court's] own prerogatives than [on] protecting fundamental rights or even the EU constitutional structure." ${ }^{49}$ Eeckhout,

48 CJEU, Opinion 1/09, EU:C:2011:123, paras. 78, 80, and 89.

49 Spaventa, "A Very Fearful Court," p. 56 (parenthesis removed). For further criticism, see, e.g., "The EU's Accession to the ECHR - a 'NO' from the ECJ!," CMLRev 52 (2015), 1-16; S. Peers, "The EU's Accession to the ECHR: The Dream Becomes a Nightmare," German Law Journal 16 (2015) 1, 213-222; P. Eeckhout, "Opinion 2/13 on EU Accession to the ECHR and Judicial Dialogue: Autonomy or Autarky," Fordham International Law Journal 38 (2015), 955-992; B. de Witte and S. Imamović, "Opinion 2/13 on Accession to the ECHR: Defending the EU Legal Order against a Foreign Human Rights Court," European Law Review 40 (2015) 5, 683-705. See also the numerous blog posts written in the days after the opinion: T. Lock, "Oops! We Did it Again - the CJEU's Opinion on EU 
for instance, argues that the CJEU has looked for problems that are not there: The fact that the accession agreement permits something whereas European Union law forbids it should not necessarily be viewed as an incompatibility. ${ }^{50}$ That Article 53 ECHR allows contracting parties to set higher standards of fundamental rights protection whereas the European Union Charter imposes a uniform standard of protection on European Union member states (which must not fall below the level set by the Convention) is only problematic if one adopts an exceptionally wide conception of conflict. ${ }^{51}$ Similarly, that member states are subject to the CJEU's exclusive jurisdiction whereas the Convention would still allow intra-European Union conflicts to be brought before the ECtHR is not really incompatible with Article 344 TFEU. $^{52}$ De Witte and Imamović similarly emphasize that the CJEU's approach is "overly strict" where it takes issue with the plausibility review carried out by the ECtHR's under the corespondent mechanism, simply because this would mean that the ECtHR would have to interpret European Union primary law with respect to the division of competences, even though it would not lead to a binding interpretation of those rules as a matter of European Union law. ${ }^{53}$ Spaventa is critical of the CJEU's stance with respect to the Common Foreign and Security Policy because the Court prefers to accept that an individual be entirely devoid of judicial protection over having another body review European Union compliance with an international treaty. ${ }^{54}$ Other scholars, notably Halberstam, have maintained that the CJEU has a number of valid concerns, which are solvable either unilaterally or by small changes to the agreement. ${ }^{55}$ That said, the majority of

Accession to the ECHR," Verfassungsblog, December 18, 2014, www.verfassungsblog.de/ en/oops-das-gutachten-des-eugh-zum-emrk-beitritt-der-eu/; W. Michl, "Thou Shalt Have No Other Courts before Me," Verfassungsblog, December 23, 2014, www.verfas sungs blog.de/en/thou-shalt-no-courts/; A. O'Neill, "Opinion 2/13 on EU Accession to the ECHR: The CJEU as Humpty Dumpty," Eutopialaw, December 18, 2014), http://eutopialaw.com/2014/12/18/opinion-213-on-eu-accession-to-the-echr-the-cjeuas-humpty-dumpty/; S. Peers, "The CJEU and the EU's Accession to the ECHR: A Clear and Present Danger to Human Rights Protection," EU Law Analysis, December 18, 2014, http://eulawanalysis.blogspot.no/2014/12/the-cjeu- and-eus-accession-to-echr.html.

50 Eeckhout, “Opinion 2/13," p. 967.

51 Ibid.

52 Ibid., p. 974.

53 de Witte and Imamović, “Opinion 2/13,” pp. 697-698.

54 Spaventa, “A Very Fearful Court," p. 53.

55 Halberstam, “A Modest Defense of Opinion 2/13,” p. 105. 
analysts agree that the possibility of accession has become more remote, ${ }^{56}$ and several of them are pessimistic about the continuation of judicial dialogue between the CJEU and the ECtHR. ${ }^{57}$ We show, however, that recent judgments like Aranyosi, ${ }^{58} \mathrm{H}$ v. Council, ${ }^{59}$ and Rosneft ${ }^{60}$ appear to signal a willingness on the part of the CJEU to iron out the differences that it listed in Opinion 2/13. ${ }^{61}$ Even if the sacrosanct formula of preserving the primacy, unity, and effectiveness of European Union law might have been a valid concern on the part of the Luxembourg judges (as pointed out by Halberstam), this chapter examines the CJEU's demonstrated ability to nuance and even compromise core principles of European Union law to cooperate with Strasbourg. Simultaneously, we discuss the ways in which the ECtHR explicitly and implicitly continues to enforce European Union law. Taken together, these two strings of case law interpretation provide a springboard for the argument that we advance here - namely, that the two courts are under a legal obligation to cooperate.

\section{Jurisprudential Cross-Fertilization}

The ECtHR's and the CJEU's competing jurisdictions have coexisted in a productive fashion for years. It has frequently been observed that their interaction is characterized by a tendency to avoid open conflicts about the scope of fundamental rights and a preference for "judicial dialogue." 62 In the main, the two courts show great respect for each other's

56 Spaventa, “A Very Fearful Court," p. 56.

57 Eeckhout, "Opinion 2/13," p. 990 ("the relationship between the CJEU and the ECtHR is unlikely to return to the past golden years of mutual respect and cooperation, let alone admiration. It will be difficult for Strasbourg not to look at [Opinion 2/13] as a rejection of its core judicial function: to serve as an external control organ for human rights violations in Europe"). More optimistically, see F. Fabbrini and J. Larik, "The Past, Present and Future of the Relation between the European Court of Justice and the European Court of Human Rights," Yearbook of European Law 35 (2016) 1, 145-179.

58 CJEU, Judgment in Aranyosi, C-404/15 and C-659/15 PPU, EU:C:2016:198.

59 CJEU, Judgment in H v. Council, C-455/14 P, EU:C:2016:569.

60 CJEU, Judgment in Rosneft, C-72/15, EU:C:2017:236, paras. 62-81.

61 See J. Snell, "Is Opinion 2/13 Obsolescent?," European Law Review 42 (2017), 449-450.

62 See, e.g., Spielmann, "The Judicial Dialogue"; Fabbrini and Larik, "The Past, Present and Future"; T. Lock, The European Court of Justice and International Courts (Oxford and New York: Oxford University Press, 2015), 167 ff. Gragl, "An Olive Branch from Strasbourg"; Douglas-Scott, "A Tale of Two Courts." On judicial dialogue generally, see Eeckhout, "Opinion 2/13," p. 955; A-M. Slaughter, "A Global Community of Courts," Harvard International Law Journal 44 (2003), 191-219. 
decisions and have demonstrated a degree of deference toward one another. This does not mean that there are no inconsistencies between the case law of Strasbourg, on the one hand, and that of Luxembourg, on the other, ${ }^{63}$ or that incompatibilities are swept under the carpet in the name of good neighborly relations. Rather, the decisions of both courts leave room for mutual accommodation. Where conflicts occur, they are often presented as an opportunity for convergence, as spurring a race to the top. Thus, as Fabbrini and Larik recently put it, the ECtHR and the CJEU are engaged in a "virtuous competition," 64 mutually influencing each other's decisions.

A conspicuous sign of this mutual influence is the citing of one another's case law, even where there is no jurisdictional overlap. Such references are much more common in judgments of the CJEU, simply because it has considered itself bound by the ECHR since the 1970s. That said, while the Luxembourg court referred to the Convention as early as $1975,{ }^{65}$ it took until 1996 for that court to rely explicitly on the case law of its brethren in Strasbourg. ${ }^{66}$ The latter, by contrast, had already made a reference to a CJEU judgment as early as 1979, in its landmark judgment in Marckx v. Belgium, and started invoking the European Union Charter as persuasive authority in 2002, even before the CJEU first relied on it. ${ }^{67}$ Still, the ECtHR has only sporadically cited Luxembourg case law, ${ }^{68}$ probably because it is the court exclusively adjudicating

${ }^{63}$ For a good (though already somewhat dated) overview, see J. Callewaert, "The European Convention on Human Rights and European Union Law: A Long Way to Harmony," European Human Rights Law Review (2009), 768-783. See earlier D. Spielmann, "Human Rights Case Law in the Strasbourg and Luxembourg Courts: Conflicts, Inconsistencies, and Complementarities," in P. Alston, M. Bustelo, and J. Heenan (eds.), The EU and Human Rights (Oxford and New York: Oxford University Press, 1999), pp. 757-780 [766].

64 Fabbrini and Larik, “The Past, Present and Future," pp. 174-175 and, more generally, F. Fabbrini, Fundamental Rights in Europe (Oxford and New York: Oxford University Press, 2014)

65 CJEU, Judgment in Rutili, 36/75, EU:C:1975:137, para. 32.

66 CJEU, Judgment in P v. S, C-13/94, EU:C:1996:170, para. 16. As Douglas-Scott observes, this is somewhat ironic given that the Court had just held that the European Union lacked competence to accede to the Convention in Opinion 2/94, EU:C:1996:140.

67 ECtHR, Goodwin v. UK, Application No. 28957/95, para. 100; CJEU, Judgment in JégoQuéré, C-263/02 P, EU:C:2004:210, para. 47. The CFI - now the General Court - was earlier to mention the Charter, see CFI, Judgment in Max.mobil, T-54/99, EU:T:2002:20, para. 48.

68 See, e.g., ECtHR, Judgment in Posti and Rakho v. Finland, Application No. 27824/95, para. 53; ECtHR, Judgment in Nada v. Switzerland, Application No. 10593/08, para. 212 (referring to the CJEU, Judgment in Kadi, C-402/05 P and C-415/05 P, EU:C:2008:461, 
on human rights, and fundamental rights decisions were relatively rare in Luxembourg for a long time. ${ }^{69}$

With the adoption of the Charter, however, this all seems to be changing. The absence of references to the Convention or to Strasbourg decisions in more recent CJEU jurisprudence is notable. ${ }^{70}$ Vice versa, the ECtHR has started to cite CJEU case law more frequently since the Charter became binding. As Dean Spielmann, the former president of the ECtHR and now judge at the General Court of the European Union has noted, this is explained by the reasons that initially prompted both supranational courts to interact with the case law of one another. The CJEU now no longer needs to refer to the judgments of the ECtHR to legitimize its own case law or the autonomy of European Union law visà-vis national constitutional courts, while, to the ECtHR, "referring to EU law offered a basis to show contemporary consensus and modernize the interpretation of the Convention," living instrument, to be interpreted in present-day conditions." 72

The same considerations are at stake when it comes to substantive cross-fertilization between the CJEU and the ECtHR. Strasbourg takes advantage of the Charter and the jurisprudence of the CJEU to update its construction of Convention rights, raising the bar of fundamental rights protection. Luxembourg pays close attention to Strasbourg's decisions not just because Article 52 of the Charter and Article 6 TEU require it but

para. 299 for the proposition that "the principles governing the international legal order under the United Nations" do not exclude all forms of judicial review of the internal lawfulness of an European Union regulation merely because that measure is intended to give effect to a Security Council resolution adopted under Chapter VII of the UN Charter, and applying it mutatis mutandis in the context of the Convention); ECtHR, Judgment in Scoppolla v. Italy (No. 2), Application No. 10249/03, paras. 105-106 (referring to CJEU, Judgment in Berlusconi, C-387/02, C-391/02, and C-403/02, EU:C:2005:270) as proof that a consensus had emerged that the retroactivity of the more lenient penalty was a fundamental principle of criminal law).

69 Douglas-Scott, "The Court of Justice of the European Union," p. 158. Moreover, as Spielmann has observed, before the advent of the Charter, when the CJEU dealt with fundamental rights issues - usually in the context of free movement law - it tended to leave much to the national court (Spielmann, "Human Rights Case Law"). This hesitation arguably made those judgments less interesting to the Strasbourg court.

${ }^{70}$ Compare, for instance, the Judgment in Akzo Nobel, C-550/07 P, EU:C:2010:512 with the opinion of the Advocate General Kokott in that case (EU:C:2010:229).

71 Spielmann, “The Judicial Dialogue," p. 11.

72 ECtHR, Judgment in Tyrer v. UK, Application No. 5856/72, para. 31. See also ECtHR, Judgment (Preliminary Objection) in Loizidou v. Turkey, Application No. 15318/89, paras. $71-73$. 
also to retain its legitimacy in the eyes of national constitutional courts. ${ }^{73}$ It must be added here that, as the cases dealing with the Dublin Regulation and the European Arrest Warrant have demonstrated, ${ }^{74}$ the CJEU's concern for fundamental rights is somewhat attenuated by what the Court understands to be its primary mission: ensuring the uniformity, primacy, and effectiveness of Union law in general, and upholding the system of mutual recognition (in turn based on mutual trust!) in particular. ${ }^{75}$ Although the ECtHR shows a remarkable degree of deference to the demands of European Union law, these cases illustrate why full compliance with the Convention may represent a challenge to the CJEU.

That said, there are many examples of the Luxembourg court adapting its case law in view of a decision of the Strasbourg court, and vice versa. The most radical example is Spain v. UK, where the CJEU sanctioned UK legislation that departed from European Union primary law because said legislation was adopted to comply with the ECtHR's judgment in Matthews v. UK. ${ }^{76}$ Similarly, in Roquette Frères, ${ }^{77}$ in a reaction to the ECtHR's decision on the scope of Article 8 ECHR in Niemietz v. Germany, ${ }^{78}$ the CJEU altered its definition of the "home" as set out in Hoechst ${ }^{79}$ so as to encompass not just private but also business premises. In N.S., the Luxembourg court introduced an exception to the principle of mutual trust underpinning the Dublin Regulation in response to M.S.S. v. Belgium and Greece. In the latter decision, the Strasbourg court had found that Belgium had infringed Article 3 ECHR by sending the applicant, an asylum seeker, to Greece, and thus exposing him to the risks linked to the systemic deficiencies in the asylum procedures of that member state and to the detention and appalling living conditions there, in breach of that provision. In N.S., the CJEU held that

73 See, e.g., the Order of 15 December 2015 of the German Bundesverfassungsgericht, Case 2 BvR 2735/14 ("European Arrest Warrant II"), See T. Reinbacher and M. Wendel, "The Bundesverfassungsgericht's European Arrest Warrant II Decision," Maastricht Journal of European and Comparative Law 23 (2016), 702-713.

${ }^{74}$ See in particular CJEU, Judgment in N.S., C-411/10 and C-493/10, EU:C:2011:865; Melloni, para. 60.

75 See further T. Van den Sanden, "Case Note Joined Cases C-411/10 \& C-493/10, N.S. v. Sec'y of State for the Home Dep't," Columbia Journal of European Law 19 (2013), 143-174.

76 CJEU, Judgment in Spain v. UK, C-145/04, EU:C:2006:543, paras. 60, 90 and 95; Matthews v. UK.

77 CJEU, Judgment in Roquette Frères, C-94/00, EU:C:2002:603, para. 29.

78 ECtHR, Judgment in Niemietz v. Germany, Application No. 13710/88.

79 CJEU, Judgment in Hoechst, 46/87 and 227/88, EU:C:1989:337. 
a member state must not transfer an asylum seeker to the "responsible Member State" within the meaning of the Dublin Regulation "where they cannot be unaware that systemic deficiencies in the asylum procedure and in the reception conditions of asylum seekers in that Member State amount to substantial grounds for believing that the asylum seeker would face a real risk of being subjected to inhuman or degrading treatment within the meaning of that provision." 80 This formulation suggested that the mutual trust principle, so central to the Dublin system, would only temporarily cease to apply where there were generalized, serious, and widespread problems with the asylum system in a member state. However, in Aranyosi, which did not concern the transfer of an asylum seeker under the Dublin system but the surrender of a detainee to another member state following a European Arrest Warrant, the CJEU slightly but fundamentally reformulated the exception, arguably to bring it more in line with the decisions in M.S.S. v. Belgium and Greece and Tarakhel, ${ }^{81}$ which laid down a criterion of "individual risk" rather than "systemic risk." According to Aranyosi, ${ }^{82}$ deficiencies need not necessarily be systemic or generalized; what is most important is that there is a "real risk of inhuman or degrading treatment by virtue of the general conditions of detentions" and, ${ }^{83}$ if so, that the national court makes "a specific and precise [assessment] of whether there are substantial grounds to believe that the individual concerned will be exposed to that risk." Despite the strong language used in Opinion 2/13, about the importance of protecting the principle of mutual trust against the detrimental impact of accession to the Convention (in the form envisaged by the Draft Agreement), ${ }^{85}$ both judgments show that the CJEU has been willing to nuance, and even compromise, one of the core principles of European Union law to meet the substantive demands posed by the Convention. ${ }^{86}$

80 N.S., para. 106 (emphasis added).

81 ECtHR, Judgment in Tarakhel v. Switzerland, Application No. 29217/12, paras. 102-104.

82 Aranyosi, paras. 88 and 91-94.

83 Ibid., para. 88.

84 Ibid., para. 91.

85 Opinion 2/13, EU:C:2014:2454, paras. 191-194.

${ }^{86}$ See further K. Lenaerts, "La Vie Après l'Avis: Exploring the Principle of Mutual (Yet Not Blind) Trust," CMLRev 54 (2017), 805-840; F. Korenica and D. Doli, "No More Unconditional 'Mutual Trust' between the Member States: An Analysis of the Landmark Decision of the CJEU in Aranyosi and Caldararu," European Human Rights Law Review (2016), 542-555. 
In turn, the ECtHR has borrowed from the CJEU on several occasions. For instance, in Stec and Others v. United Kingdom, it effectively followed a CJEU decision in finding the difference in national pensionable age between men and women to pursue a legitimate aim and to be reasonably and objectively justified. The ECtHR explicitly mentioned that "particular regard should be had to the strong persuasive value of the ECJ's finding on this point." ${ }^{87}$ In Scoppola v. Italy (No. 2), the Strasbourg court invoked Article 47 of the European Union Charter to revise its case law on Article 7 ECHR and cited the CJEU's Berlusconi judgment to prove that a consensus had arisen that the retroactivity of the more lenient penalty was a fundamental principle of criminal law.

The mutual influence between the two courts is even clearer when the ECtHR deals with European Union law and thereby contributes directly to its development. A good example of this is the long line of cases in which the Strasbourg court is asked to review a national court's failure to make a reference for a preliminary ruling in the light of Article 6 ECHR. ${ }^{88}$ Although such a ground for review might raise concern with the CJEU (because the ECtHR is not concerned with ensuring the primacy and uniformity of European Union law but only with safeguarding fundamental rights) the Strasbourg court has diligently examined the domestic court's refusal to refer in the light of the CJEU's CILFIT judgment. ${ }^{89}$ It has consistently held that Article 6(1) ECHR may be infringed due to the arbitrary refusal of a request of a party in the national proceedings asking the domestic court to make a reference to the CJEU. In Dhahbi v. Italy and Schipani and Others v. Italy, ${ }^{90}$ the ECtHR has found a violation of that provision for the first time because the Italian Court of Cassation had refused to make a reference without stating the reasons for its refusal. This ECtHR case law implicitly reinforces the CJEU's jurisprudence on Article 267 TFEU.

In yet other cases, the ECtHR explicitly reinforces European Union law. For instance, the Strasbourg court has held on several occasions that the cooperation between the national courts of European Union member states, on the one hand, and the CJEU, on the other, is of great importance

87 ECtHR, Judgment in Stec and Others v. UK, Application Nos. 65731/01 and 65900/01, para. 58.

88 See C. Lacchi, “The ECrtHR's Interference in the Dialogue between National Courts and the Court of Justice of the EU: Implications for the Preliminary Reference Procedure," Review of European Administrative Law 8 (2015), 95-125.

89 CJEU, Judgment in CILFIT, 77/83, EU:C:1984:91.

${ }^{90}$ Dhahbi v. Italy, paras. 31-34 and Schipani and Others v. Italy, paras. 69-73. 
for the protection of fundamental rights. ${ }^{91}$ By both implicitly and explicitly reinforcing European Union law, the ECtHR de facto enforces the European Union law principle of sincere cooperation through the Convention. Similarly, in its judgment in Avotiņ̌ v. Latvia - the ECtHR's reaction to Opinion 2/13, discussed previously - Strasbourg held that "where the courts of a State which is both a Contracting Party to the Convention and a Member State of the European Union are called upon to apply a mutual recognition mechanism established by EU law, they must give full effect to that mechanism where the protection of Convention rights cannot be considered manifestly deficient." 92 This friendly formulation, by which the ECtHR acknowledges the importance of the European Union law principle of mutual trust and enforces it, as mediated by the Convention, may be viewed as an olive branch to the Luxembourg court. ${ }^{93}$ The practice of the ECtHR to reinforce European Union law using the toolkit of the Convention shows that the fears expressed by the CJEU in Opinion 2/13 might indeed be overstated.

Finally, the case law on the judicial review of UN sanctions provides perhaps the best example of cross-fertilization in the true sense of the word. In the Kadi (I and II) and Nada v. Switzerland cases, the two courts "drew from each other's example, and simultaneously pushed each other to adopt even more expansive human rights approaches." ${ }^{\prime 4}$ In Kadi, the CJEU famously held that international law did not bar it from reviewing with European Union fundamental rights the compatibility of an European Union regulation that implemented a UN Security Council resolution laying down sanctions (the review was not limited to jus cogens, as the General Court had held). ${ }^{95}$ In Nada v. Switzerland, the ECtHR explicitly relied on that passage from Kadi to hold that UN sanctions could not ride roughshod over the guarantees offered by the Convention. ${ }^{96}$ Moreover, it added that the contracting parties have several positive

91 See, e.g., Michaud v. France, paras. 110-111.

92 Avotinšs v. Latvia, para. 116.

93 More hesitant, see Gragl, “An Olive Branch from Strasbourg," p. 565 (awarding less importance to the CJEU's judgment in Aranyosi and underlining that Strasbourg requires member states to play a more active role in examining compliance with fundamental rights than Luxembourg does when it asks domestic courts automatically to recognize or enforce decisions originating in another member state).

94 Fabrinni and Larik, "The Past, Present and Future," pp. 175-176.

95 CJEU, Kadi, paras. 285, 288, 306-308, and 326. Compare with CFI, Judgment in Kadi, T-315/01, EU:T:2005:332, paras. 226-231. Interestingly, even in Kadi, the CJEU already relied on Strasbourg case law.

96 Nada v. Switzerland, para. 212. 
obligations, notably to try and delist individuals who have been cleared in domestic terrorism-related investigations or to offer them assistance in requesting an exemption for health reasons from the UN Sanctions Committee. ${ }^{97}$ In turn, in Kadi II, the CJEU, ignoring warnings from the advocate general to attenuate its rash view on the relationship between the UN Charter and human rights, ${ }^{98}$ doubled down on its first judgment by deciding that unless they are willing or able to fully disclose all evidence against them, the European Union institutions must delist individuals ("disclose or delist"). 99 This example of cross-fertilization between both courts - along with others ${ }^{100}$ - demonstrates that "the influence the one exerts on the other is mutual and real."101

\section{Beyond Comity? The Normative Case for Judicial Dialogue}

Is it possible to identify a legal duty, however weak, for both courts to continue their dialogue? On the European Union side, the Declaration on Article 6(2) TEU annexed to the Treaty of Lisbon is a small step in that direction. ${ }^{102}$ In the terse wording of the Declaration, the Intergovernmental Conference "notes the existence of a regular dialogue between the Court of Justice of the European Union and the European Court of Human Rights" and concludes by observing that "such dialogue could be reinforced when the Union accedes to that Convention." According to

97 Ibid., paras. 187-196.

98 Opinion of Advocate General Bot in Kadi II.

99 Kadi II, paras. 111 and 123.

100 Another, earlier illustration, is the ECtHR's reliance on Article 9 of the European Union Charter as proof of consensus that the right to marry in Article 12 of the Convention must be construed to give transsexuals the right to marry a person of the sex to which they previously belonged (in Goodwin v. UK, para. 100). The CJEU later relied on that judgment in holding that national legislation preventing transsexuals from fulfilling the marriage requirement that must be met for one of them to be able to benefit from a survivor's pension - which forms part of the pay of one of them - violated the right to equal pay for male and female workers enshrined in what is now Article 157 TFEU (Judgment in K.B., C-117/01, EU:C:2004:7, paras. 33 and 36). S. Iglesias Sánchez called this a "boomerang effect" ("The Court and the Charter: The Impact of the Entry Into Force of the Lisbon Treaty on the ECJ's Approach to Fundamental Rights," CMLRev 49 [2012], 1565, 1570), but it might be viewed as cross-fertilization.

101 As a CJEU judge, writing extrajudicially, put it: see C. Timmermans, "The Relationship between the European Court of Justice and the European Court of Human Rights," in A. Arnull, C. Barnard, M. Dougan, and E. Spaventa (eds.), A Constitutional Order of States: Essays in Honour of Alan Dashwood (Oxford: Hart Publishing, 2011), pp. 151-160 [153].

102 OJ (2016) C 202/337. 
Douglas-Scott, this puts the CJEU and the ECtHR under a political obligation to continue their dialogue and even intensify it. ${ }^{103}$ That, however, leaves unanswered the question whether a legal obligation to the same effect exists. It might seem that the CJEU must, based on the text of the Charter, engage with ECtHR case law when applying the Charter; arguing for the existence of an unwritten legal obligation to engage in a dialogue would not add anything to the legal obligation already spelled out in Article 52 of the Charter. However, cases like N.S., as well as cases emphasizing the European Union's autonomy, demonstrate that the CJEU doesn't always wholeheartedly follow the case law of the Strasbourg Court. Conversely, the question remains open as to a legal duty for the ECtHR to cooperate with the CJEU.

Judicial dialogue is usually described as a form of judicial comity, a label that covers a variety of cooperative practices between judges (usually) belonging to different legal systems. ${ }^{104}$ Scholars rely on the concepts of comity and dialogue to give a descriptive account of how two courts endeavor to avoid conflict in a situation where it is unsettled which of both has ultimate authority. That is notably the case (1) in the relationship between national constitutional courts and the CJEU, both of whom claim to have the final say over the validity of European Union law; ${ }^{105}(2)$ in horizontal conflicts of law situations ${ }^{106}$ in which

103 Douglas-Scott, “The Court of Justice of the European Union," p. 160. The Joint Communication from Presidents Costa and Skouris of 24 January 2011 (http://curia.europa .eu/jcms/upload/ docs/application/pdf/2011-02/cedh_cjue_english.pdf) also mentions that both courts hold regular meetings and will continue their dialogue with respect to the issues raised by accession.

104 E. D’Alterio, “From Judicial Comity to Legal Comity: A Judicial Solution to Global Disorder?," International Journal of Constitutional Law 9 (2011) 2, 394. For a broader conception of dialogue in Luxembourg and Strasbourg as a legitimizing nexus not only between courts but also between courts and civil society, and courts and legislatures, see B. Petkova, "Three Levels of Dialogue in Precedent Formation at the CJEU and ECtHR," in K. Dzehtsiarou, T. Konstantinides, T. Lock, and N. O’Meara (eds.), Human Rights Law in Europe: The Influence, Overlaps and Contradictions of the EU and ECHR (London: Routledge, 2014), 73-91.

105 M. Claes, "The Validity and Primacy of EU Law and the 'Cooperative Relationship' between National Constitutional Courts and the Court of Justice of the European Union," Maastricht Journal of European and Comparative Law 23 (2016), 151.

106 See, e.g., A. Briggs, "The Principle of Comity in Private International Law," Collected Courses of the Hague Academy of International Law (Leiden, The Netherlands and Boston: Brill, 2012); J. R. Paul, "The Transformation of International Comity," Law and Contemporary Problems 71 (2008), 19-38. 
two courts have a plausible claim to jurisdiction; or (3) between the ECtHR and the CJEU. ${ }^{107}$

It has become a trope today to label such situations as instances of "legal pluralism" to make the point that positive law cannot resolve these conflicts and is unable to create harmony between legal systems. ${ }^{108}$ Judicial comity, and judicial dialogue in particular, is heralded as the alternative: It is not a matter of legal rules but of de facto courtesy and mutual respect between courts that do not stand in hierarchical relationship to each other. While it may not always succeed, its function is to prevent and mediate the conflict to which pluralism is prone to give rise and promote harmonization and even integration. ${ }^{109}$

Judges use different techniques to express comity. Judicial dialogue typically involves the referencing and mutual consideration of each other's decisions as persuasive or even quasi-binding authority with the aim of "harmonizing judicial solutions." 110 Yet, even the brinkmanship of an explicit warning shot addressed at another court that then responds by accommodating the concerns of the first - while perhaps raising a few of its own - may qualify as such. Another technique is giving "full faith and credit" to decisions of "foreign" courts. Such recognition promotes integration by allowing the laws of two legal systems to apply simultaneously in the same jurisdiction, with the effect that rights acquired within one legal system retain their legal force in the other. ${ }^{11}$ A last instance of judicial comity worth mentioning here involves deferring to the jurisdiction of another court, for instance because it is better placed to solve the dispute (forum non conveniens) or in the interest of international cooperation and regional integration, as the ECtHR does by applying its Bosphorus presumption or the German Bundesverfassungsgericht through its Solange doctrine. ${ }^{112}$

In the context of European Union-ECHR relations, there is a case to be made that these cooperative practices go beyond mere comity. As Eeckhout has argued, the national, European Union, and ECHR systems

\footnotetext{
107 Douglas-Scott, “The Court of Justice of the European Union," p. 160.

108 Eeckhout, "Human Rights and the Autonomy of EU Law," p. 175.

109 E. D'Alterio, "From Judicial Comity to Legal Comity," International Journal of Constitutional Law 9 (2011), 394-424 [398, 401, 402].

110 Ibid., 402.

111 Ibid., 400-401. See also the references mentioned in note 106.

112 Ibid., 402.
} 
must be conceived as integrated rather than pluralist, ${ }^{113}$ which means that conflicts between the supreme adjudicators of each system take place within the law. Even if the CJEU and the ECtHR may occasionally differ on the interpretation or application of the Convention, this does not warrant the conclusion that there is a deep conflict of ultimate judicial authority that is not subject to legal argumentation. ${ }^{114}$ On the one hand, there are legal rules and principles binding on all the judicial actors involved that determine the limits of their respective jurisdiction. ${ }^{115}$ In case in which they disagree about the interpretation or application of these rules, such conflicts can be solved through non-adjudicative legal means, such as constitutional amendment. ${ }^{116}$ On the other hand, where courts share jurisdiction - as they are likely to do because the integration of the national and ECHR system into the European Union system means that the three systems share norms - conceiving of these three legal systems as part of an integrated whole imposes, as a matter of obligation, a true judicial dialogue through which courts may jointly craft interpretations that fit the various legal systems involved. ${ }^{117}$ Just like the integration of European Union law into national law requires regular cooperation between national courts and the CJEU based on the principle of sincere cooperation, ${ }^{118}$ the integration of the Convention

113 Eeckhout, "Human Rights and the Autonomy of EU Law," $177 \mathrm{ff}$. To summarize Eeckhout's point: post-Lisbon, both the Convention and fundamental rights resulting from the constitutional traditions common to the member states are fully integrated into European Union constitutional law. For its part, the European Union Charter does not diverge from the Convention but carefully regulates its relationship to it in conformity with Article $53 \mathrm{ECHR}$, and there even is some integration of the European Union Charter into ECtHR case law despite the absence of legal links. Conversely, all European Union human rights law is integrated into national law through the principles of primacy and direct effect. The picture that emerges is one in which the national and ECHR fundamental rights systems are integrated into the European Union system, which remains tributary to the laws of the member states and to the Convention, both of which have their own judicial system with ultimate interpretive authority.

114 Ibid., 188.

115 Ibid., 180.

116 Ibid., 187.

117 Ibid.

118 See the View of Advocate General Mazák in Melki, C-188/10 and C-189/10, EU: C:2010:319, point 64 (observing that the preliminary ruling procedure is vital to ensure the uniform and coherent application of European Union law and requires the CJEU and national courts to proceed "in a spirit of cooperation and on the basis of mutual trust and judicial dialogue"). See also K. Lenaerts, "Interlocking Legal Orders in the European Union and Comparative Law," International and Comparative Law Quarterly 
into European Union law makes dialogue between the CJEU and the ECtHR mandatory as a matter of law.

As alluded before, that argument might seem somewhat overwrought in so far as the CJEU is concerned. Does it not suffice that the treaties explicitly integrate the Convention into the European Union legal order, which means that the European Union institutions are bound by ECtHR jurisprudence as a matter of European Union law? This is true to some extent. Although formally the treaties refer only to the Convention, the explanations relating to Article 52(3) of the Charter clarify that the "meaning and scope" of the rights guaranteed by the Convention must be determined by reference to both the text of the Convention and the case law of the ECtHR. ${ }^{119}$ As discussed, this provision requires the Luxembourg court to follow the case law of the Strasbourg Court to ensure that corresponding Charter rights afford the same level of protection, including authorized limitations. ${ }^{120}$ That being said, neither Article 6 TEU nor Articles 52 and 53 of the Charter clearly spell out a duty for the Luxembourg court to cooperate with its Strasbourg-based counterpart and to strive for harmony and coherence between both systems. The procedural duty to cooperate, for instance by engaging in a constructive dialogue, goes beyond the simple obligation to comply which, as Opinion $2 / 13$ highlights, is attenuated inter alia by the autonomy of European Union law. ${ }^{121}$

When it comes to the ECtHR, that court's practice of deferring to the CJEU on matters involving European Union law must arguably be viewed, not as mere comity but partly as a straightforward consequence of Strasbourg's lack of jurisdiction over European Union law, and partly

52 (2013), 873-906 [879 and 882-883], who explains that the dialogue conducted in the context of the preliminary ruling procedure allows the CJEU to find solutions that do not unnecessarily upset national sensitivities and thus make the national legal orders have confidence in the European Union legal order. While European Union law technically has primacy, it relies on the national courts for its application. To ensure the effective application of European Union law in the member states, the Court "takes the pulse" of the national legal systems and, through the comparative method, develops a compromise solution that is sufficiently common to the member states.

119 Explanations relating to Article 52(3) of the Charter of Fundamental Rights, OJ (2007) C $303 / 33$.

120 Ibid.

121 See also explanations relating to Article 52(3) of the Charter of Fundamental Rights, OJ (2007) C 303/33, which mention the importance of "the autonomy of Union law and that of the [CJEU]." 
as an obligation to avoid conflict through dialogue. The ECtHR has never held a European Union member state responsible for European Union acts stricto sensu. It accomplishes this inter alia by narrowly defining state action - the jurisdictional nexus required for the ECtHR to examine an European Union member state's Convention responsibility for acts and omissions required by European Union law, by not lightly presuming that member states transferred powers to the European Union with the intent to circumvent their obligations under the Convention, and by setting a high bar for rebutting the presumption of equivalent protection. ${ }^{122}$ Rather than as a discretionary decision of the ECtHR not to exercise its jurisdiction over cases involving European Union law comity - this jurisprudence may have to be conceived as evidence that, on a proper construction of it, the Court's jurisdiction simply does not extend that far. After all, as Reyngaert has argued, the ECtHR's jurisdiction ought to be interpreted in keeping with the generally accepted international law principle that member states cannot generally be held liable for the acts of international organizations by virtue of their membership of that international organization alone. ${ }^{123}$ This would amount to a denial of the international legal personality of said international organization and make its functioning impossible. In other words, the legitimate and weighty interest in securing the proper functioning of international organizations, to which the ECtHR referred in Bosphorus, ${ }^{124}$ is a principle of international law that imposes legal obligations. Strasbourg's deferential attitude toward European Union law is not purely a matter of comity but is grounded in law.

Further support for the claim that the judicial dialogue between the ECtHR and the CJEU is a matter of obligation may arguably be found in the principle of systemic integration expressed by Article 31(3)(c) of the Vienna Convention on the Law of Treaties. That provision, which is generally considered to be part of customary international law, ${ }^{125}$ requires the interpreter of a treaty to consider "any relevant rules of international law applicable in relations between the parties." It conveys the objective of system integration (or "systemic harmonization," as the

122 See Reyngaert, “The European Court of Human Rights' Approach to the Responsibility of Member States," p. 997 et passim.

123 Ibid.

124 Bosphorus v. Ireland, paras. 150-157.

125 O. Dörr, “Article 31: General Rule of Interpretation," in O. Dörr and K. Schmalenbach, Vienna Convention on the Law of Treaties: A Commentary (Vienna: Springer, 2012), p. 521, point 6 . 
ECtHR has put it in Al-Dulumi ${ }^{126}$ ), according to which all treaties, whatever their subject matter, are a creation of the international legal system and their operation is predicated on that fact. ${ }^{127}$ This gives rise to a strong presumption against normative conflict ${ }^{128}$ and an unnecessary loss of coherence (i.e., fragmentation) of the international legal order. ${ }^{129}$ Thus, parties to a treaty are presumed not to have intended to act inconsistently with generally recognized principles of international law or with previous treaty obligations toward third states. ${ }^{130}$ This may be the legal scaffolding that supports an obligation for the ECtHR not to presume too lightly that the European Union treaties conflict with the Convention. At the very least, Article 31(3)(c) VCLT puts the CJEU and the ECtHR under a weak procedural obligation to engage with the ECHR and European Union law, respectively, and to strive to "avoid conflict in the interpretation of their own constitutional treaties, so as not to undermine fundamentally the system on which they are founded."131

Ultimately, the most intuitive argument for genuine mutual cooperation between the CJEU and the ECtHR does not involve abstract notions of overlapping jurisdiction or systemic coherence but derives from the historical links and shared mission of both institutions. The Council of Europe and the European Union were established to serve the same general aim of securing peace on a war-torn continent. While it is often assumed that the latter focused on economic goals and deliberately outsourced human rights protection to the former, De Búrca has shown that the 1950s framers saw the omission of human rights from the 1957 treaties as a "pragmatic and strategic interim step," not as a "deliberate decision to consign matters of human rights in the

ECtHR, Judgment in Al-Dulumi and Montana Management v. Switzerland, Application No. 5809/08, para. 140.

127 "Fragmentation of International Law: Report of the Study Group of the International Law Commission," A/CN.4/L.702, at 13-14.

128 M. Koskkeniemi (ed.), "Fragmentation of International Law: Final Report of the Study Group of the International Law Commission,” A/CN.4/L.682, point 37.

129 K. Ziegler, "Beyond Pluralism and Autonomy: Systemic Harmonization as a Paradigm for the Interaction of EU Law and International Law," Yearbook of European Law 35 (2016), 667-711 [685].

130 ICJ, Rights of Passage over Indian Territory (Preliminary Objections) (Portugal v. India), ICJ Reports (1957), p. 142. See C. McLachlan, "The Principle of Systemic Integration and Article 31(3)(c) of the Vienna Convention," International and Comparative Law Quarterly 54 (2008), 279-320 [311].

131 K. Ziegler, "Autonomy: From Myth to Reality - or Hubris on a Tightrope? EU Law, Human Rights and International Law," University of Leicester School of Law Research Paper No. 15-25, http://papers.ssrn.com, 55-56. 
Community henceforth to the Council of Europe."132 Indeed, they specifically envisaged a robust human rights regime and a closely entwined constitutional relationship between the eommunities and the ECHR. ${ }^{133}$ In other words, these sister organizations, which today share the European flag and anthem, were meant jointly to create a sort of European public order that would prevent member states from backsliding into fascism or totalitarianism. Fidelity to this idea ultimately provides the most basic and compelling reason for avoiding unproductive judicial skirmishes and encouraging good faith cooperation between the Luxembourg and Strasbourg court.

132 G. De Búrca, "The Road Not Taken: The European Union as a Global Human Rights Actor," American Journal of International Law 105 (2011), 649-693 [692].

133 Ibid., 673. 


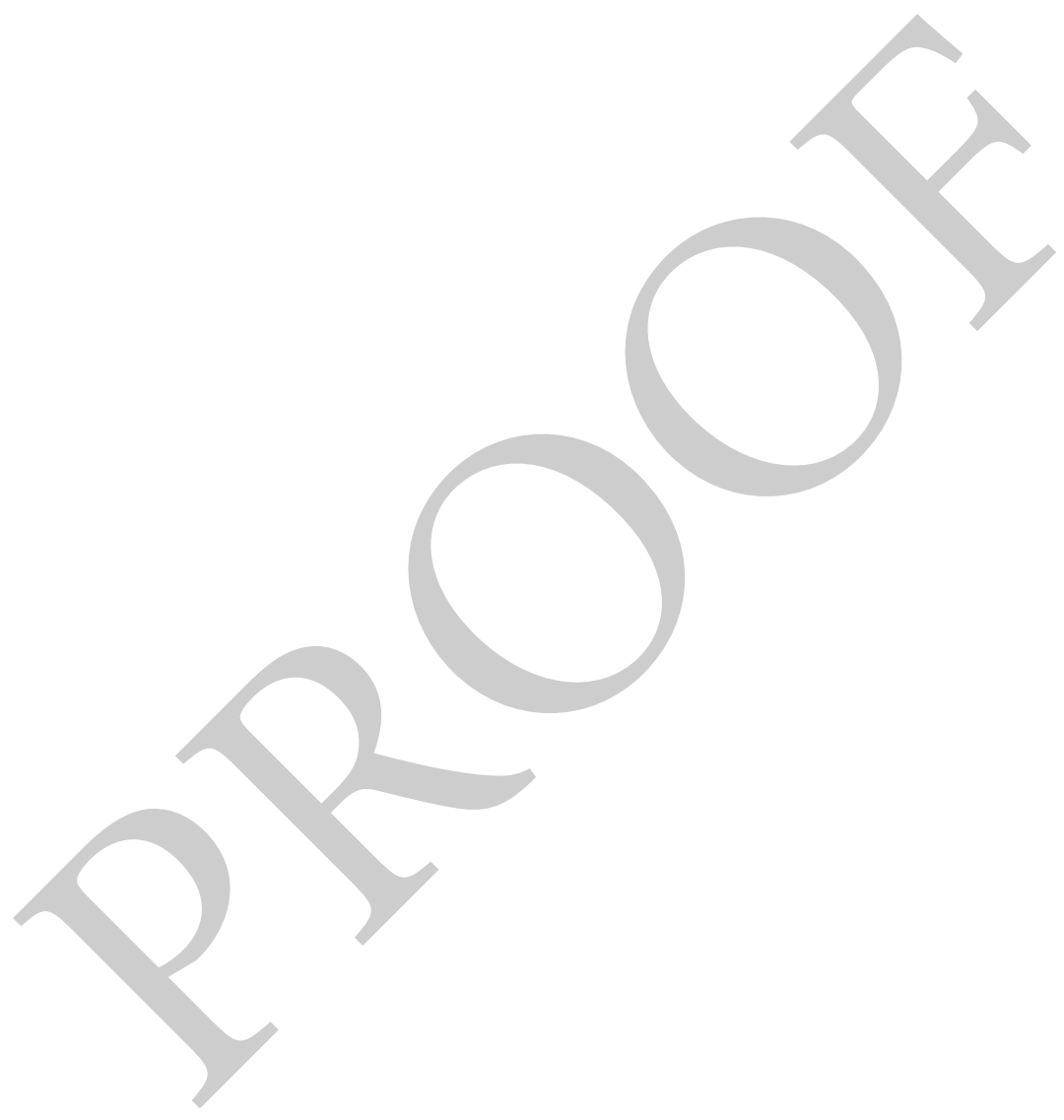

